\title{
POSTERIOR CERVICAL FORAMINOTOMY: ANATOMIC STUDY IN CADAVERS
}

\author{
FORAMINOTOMIA CERVICAL POSTERIOR: ESTUDO ANATÔMICO EM CADÁVERES \\ FORAMINOTOMÍA CERVICAL POSTERIOR: ESTUDIO ANATÓMICO EN CADÁVERES
}

Aluizio Augusto Arantes Júnior ${ }^{1}$, Francisco Alves de Araújo Júnior ${ }^{1}$, José Augusto Malheiros ${ }^{1}$, Sebastião Nataniel Silva Gusmão",

Arthur Adolfo Nicolato², Gabriel Gouvela²

\begin{abstract}
Objective: This study was designed to use different segments of the cervical spine in cadavers to determine how much lateral mass should be resected for adequate foraminal decompression. Methods: Six cadavers were used. The region of the cervical spine from C1 to the C7-T1 transition was dissected and exposed. The lateral mass of each vertebra was measured bilaterally before the foraminotomy in the following segments: C2-C3, C3-C4, C4-C5, C5-C6 and C6-C7. The procedure was performed with a high-speed drill and through surgical microscopy. Three foraminotomies were performed (F1, F2, F3) in each level. Lateral masses were measured after foraminotomy procedures and compared to the initial measurement, creating a percentage of lateral mass needed for decompression.. The value of the entire surface was defined as 100\%. Results: There was a statistical difference between the amounts of the resected lateral mass through each foraminotomy (F1, F2, F3) at the same level. However, there was no statistical significant difference among the different levels. The average percentage of resection of the lateral masses in F2 were 27.7\% at C2-C3, 24.8\% at C3-C4, 24.4\% at C4-C5 and 23.8\% and $31.2 \%$ at $\mathrm{C5}-\mathrm{C} 6$ and $\mathrm{C6}-\mathrm{C} 7$, respectively. In F3, the level that needed greater resection of the lateral masses was C6-C7 level, where the average resection ranged between $41.2 \%$ and $47.9 \%$. Conclusion: In all segments studied, the removal of approximately 24 to $32 \%$ of the facet joint allowed adequate exposure of the foraminal segment, with visualization of the dural sac and the exit of the cervical root.
\end{abstract}

Keywords: Foraminotomy; Spine, Cadaver.

\begin{abstract}
RESUMO
Objetivo: Utilizar diferentes segmentos da coluna cervical em cadáveres para determinar quanto de massa lateral deve ser ressecada para adequada descompressão foraminal. Métodos: Seis cadáveres foram usados e dissecados de modo a expor a região cervical posterior de C1 até a transição C7-T1. A massa lateral de cada vértebra foi medida bilateralmente antes da foraminotomia nos segmentos: C2-C3, C3-C4, C4-C5, C5-C6 e C6-C7. A foraminotomia foi realizada com "drill" de alta rotação e técnica microscópica. Três foraminotomias foram efetuadas: F1, F2, F3 em cada nível. As massas laterais foram medidas após procedimentos da foraminotomia e comparadas à medida inicial, criando uma porcentagem de massa lateral necessária para descompressão. O valor de cada face articular foi definido como $100 \%$. Resultados: Houve diferença estatística entre a quantidade de massa lateral ressecada entre cada foraminotomia (F1, F2, F3) no mesmo nível. Entretanto, não houve diferença estatística entre as foraminotomias em diferentes níveis. A porcentagem média de ressecção das massas laterais na foraminotomia F2 foi de 27,7\% em C2-C3; 24,8\% em C3-C4; 24,4\% em C4-C5; 23,8\% em C5-C6; 31,2\% em C6-C7. $\mathrm{Na}$ foraminotomia F3, o nível que precisou de maior ressecção das massas laterais foi C6-C7, onde a foraminotomia variou entre 41,2\% e 47,9\%. Conclusão: Em todos os segmentos estudados, a remoção de aproximadamente 24 a 32\% da articulação facetária permitiu exposição adequada do segmento foraminal com visualização do saco dural e da saída da raiz cervical.
\end{abstract}

Descritores: Foraminotomia; Coluna vertebral; Cadáver.

\section{RESUMEN}

Objetivo: Utilizar diferentes segmentos de la columna cervical en cadáveres para determinar cuánto de masa lateral debe ser resecada para la adecuada descompresión foraminal. Métodos: Seis cadáveres fueron usados y disecados de modo a exponer la región cervical posterior de C1 hasta la transición C7-T1. La masa lateral de cada vértebra fue medida bilateralmente, antes de la foraminotomía, en los segmentos: C2-C3, C3-C4, C4-C5, C5-C6 y C6-C7. La foraminotomía fue realizada con "drill" de alta rotación y técnica microscópica. Se efectuaron tres foraminotomías: F1, F2, F3 en cada nivel. Las masas laterales fueron medidas después de procedimientos de foraminotomía y se compararon con la medida inicial, creando un porcentaje de masa lateral necesaria para descompresión. El valor de cada faz articular fue definido como siendo 100\%. Resultados: Hubo diferencia estadística entre la cantidad de masa lateral resecada entre cada foraminotomía (F1, F2, F3) en el mismo nivel. No obstante, no hubo diferencia estadística entre las foraminotomías en niveles diferentes. El porcentaje promedio de resección de las masas laterales, en la foraminotomía F2, fue de 27,7\% en C2-C3; 24,8\% en C3-C4; 24,4\% en C4-C5; 23,8\% en C5-C6; 31,2\% en C6-C7. En la foraminotomía F3, el nivel que precisó de más resección de las masas laterales fue C6-C7, en el cual la foraminotomía varió entre 41,2\% y 47,9\%. Conclusión: En todos los segmentos estudiados, la remoción de aproximadamente 24 a 32\% de la articulación facetaria permitió tener exposición adecuada del segmento foraminal con visualización del saco dural y de la salida de la raíz cervical.

\section{Descriptores: Foraminotomía; Columna vertebral; Cadáver.}

\footnotetext{
1. Department of Neurosurgery, Hospital das Clínicas da Universidade Federal de Minas Gerais. Belo Horizonte, MG, Brazil.
}

2. Escola de Medicina da Universidade Federal de Minas Gerais. Belo Horizonte, MG, Brazil.

The study was conducted in the Laboratory of Anatomy and Microneurosurgery, Escola de Medicina da Universidade Federal de Minas Gerais Belo Horizonte, MG, Brazil. Correspondence: Rua dos Inconfidentes 320/801, Belo Horizonte, MG, Brazil, 30140-120. aluizio_arantes@uol.com.br 


\section{INTRODUCTION}

Posterior cervical foraminotomies have been used successfully to treat cervical radiculopathy. ${ }^{1-2}$ This technique, which was initially described by Scoville, consists of a lamino-foraminotomy with subsequent radicular decompression ${ }^{2-7}$ and allows for the removal of soft disc herniations and hard osteophytes. ${ }^{8-11}$

Several clinical surgical studies have been conducted to assess whether the laminoforaminotomy has applicability in various situations. The results have been satisfactory, showing over $90 \%$ clinical improvement in the immediate and late postoperative periods. ${ }^{12-14}$ The technique is particularly suitable for the treatment of nerve root compression caused by herniated discs or of foraminal stenosis or posterolateral osteophytes. ${ }^{15-17}$

Laminoforaminotomies allow the direct visualization of the root and eliminate the need for surgery on the arthrodesis segment. This method allows the maintenance of motion and avoids adjacent segment degeneration and complications related to the anterior cervical spine, such as dysphagia, dysphonia and esophageal lacerations..$^{3-11,18,19}$ However, this technique can cause cervical instability because there is a need for resection of the medial articular facet. In a cadaver study, Zdeblick et al. ${ }^{20}$ reported that a $50 \%$ resection of the facet did not cause instability. The removal of less bone during the procedure reduces the probability of causing instability.

Although there have been many studies on the subject of the laminoforaminotomy, none has addressed the anatomical specifics of access to describe how the facet should be resected for adequate exposure and root decompression. The aim of this study was to assess the amount of lateral mass that needs to be excised to efficiently promote foraminal decompression.

\section{METHODS}

\section{Specimen Preparation}

The study was conducted in the Laboratory of Anatomy and Microneurosurgery School of Medicine, Federal University of Minas Gerais. Six cadavers (four males and two females) were used.

The cadavers were fixed in $10 \%$ formalin, and all samples were subjected to dissection of the posterior occipito-cervical-thoracic region to expose the area in the craniocaudal direction from the occipito-cervical transition to the first thoracic vertebra and the articular processes toward the laterolateral direction.

\section{Foraminotomy}

To perform the procedure, the cadavers were positioned prone with slight flexion of the head region. The region was maintained in an exposed state using self-retractors. All surgery was performed using a surgical microscope (DF Vasconcelos Microscope). Lateral masses of $\mathrm{C} 2$ through $\mathrm{C} 7$ were measured bilaterally with the aid of a compass and a digital caliper before performing the procedure.

Foraminotomies were performed in the segments C2-C3, C3-C4, C4-C5, C5-C6 and C6-C7 on both sides.

The procedure began with the dissection of the space between the blades with the aid of a microsurgical dissector. The lateral mass, the blades of the upper and lower vertebrae and the ligamentum flavum (LF) were identified. Next, the lateral segment of the blades and the most medial lateral mass were removed with a high-speed drill. The LF was subsequently resected with subsequent identification of the dural sac.

We created three holes that were labeled F1, F2 and F3. The F1 hole was created to identify the dural sac, the armpit and the foraminal initial segment of the root. The F2 hole was made to identify the foraminal segment of the root and the limits defined by the distance between the medial and lateral foraminal rim. The F2 hole was used as the pattern to promote foraminal decompression. The F3 hole was created to identify the initial part of the extraforaminal segment. (Figures 1 and 2) After the placement of each hole, the remaining lateral mass was measured. We then calculated the amount of the lateral mass that was resected as a percentage, as shown in the results section.
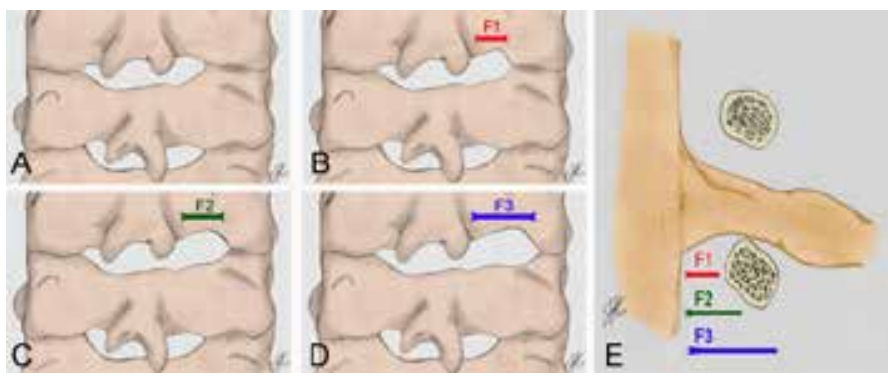

Figure 1. Schematic drawing of a cervical segment (posterior view). (A) full facet, (B) facet remaining after the first foraminotomy ( $F 1)(C)$ facet remaining after the second foraminotomy (F2), (D) facet remaining after the third foraminotomy (F3), (E) drawing showing the root segment after each foraminotomy.

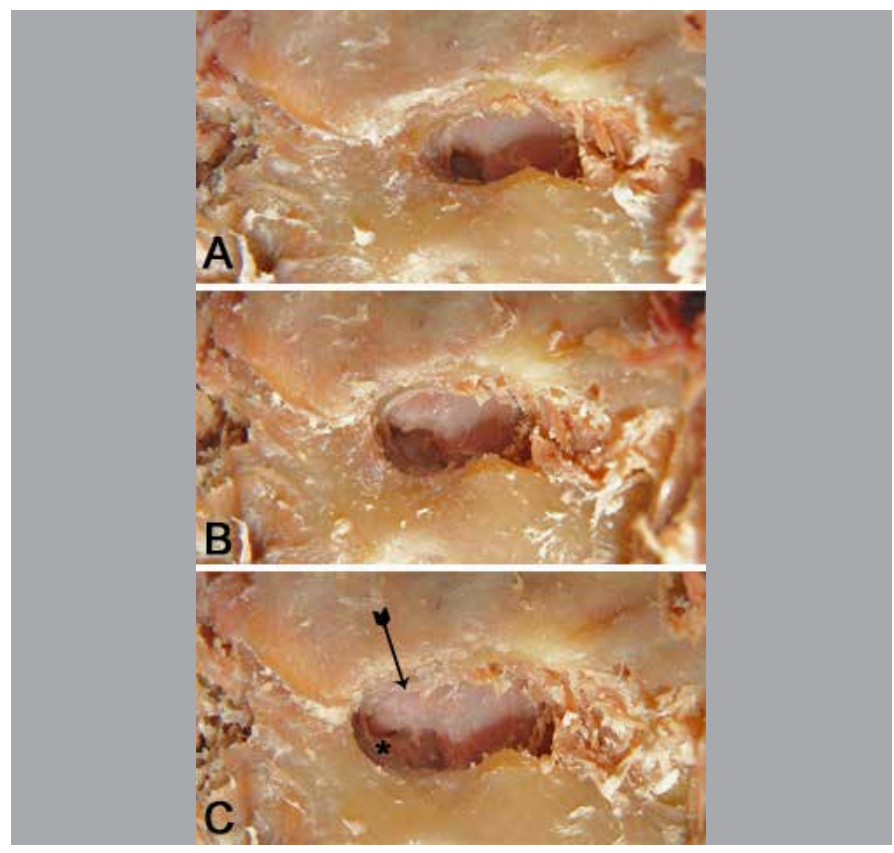

Figure 2. Photo of a C6-C7 left foraminotomy. (A) foraminotomy $\mathrm{F} 1,(\mathrm{~B})$ foraminotomy F2, (C) foraminotomy F3. Note the C7 pedicle (arrow) and the $\mathrm{C} 7$ root $\left({ }^{*}\right)$

\section{Statistical Analysis}

A descriptive analysis of the percentage of withdrawals in the three facet measurements was initially performed. The following calculations were subsequently made: mean and median, minimum and maximum, and standard deviation.

Measurements were compared using a Generalized Linear Model ANOVA that repeated measurements for three factors. We considered the $5 \%$ level of significance. To observe differences among the three measurements, which were compared two by two, we used the multiple comparison test LSD (Least Significant Difference).

We estimated confidence intervals of $95 \%$ for the mean differences for each pair of measurements: a) the percentage of the facet removed in F2 versus F1 (the withdrawal percentage facet); b) the percentage of the facet removed in F3 vs. F1 (the withdrawal percentage facet); c) the percentage of the facet removed in F3 on the F2 side.

All of the tests were performed considering both sides with stratification performed on the side that was being evaluated. A $5 \%$ level of significance was used. The analysis tool used for this study was the SPSS 12.0 software.

\section{RESULTS}

We found no differences between the right and left sides. (Table 1) The sample contains 39 segments (C2-C3 $n=12$, C3-C4 $n=11$, C4-C5 $n=11$, C5-C6 $n=11$ and C6-C7 $n=8)$. 
There was a gradual increase in the percentage of the facet removed in each of the foraminotomies independent of the segments evaluated. (Table 2)

As shown in Table 3, there were statistically significant differences between the three measurements ( $p<0.001$ ). However, no significant differences in the measurements in the five different segments were seen $(p=0.381)$. Figure 3 shows a graphical representation of the confidence intervals (95\%) of the means obtained from each of the three measurements, as organized by segment.

When all of the foraminotomies were compared, we saw statistically significant differences. The greatest difference was seen when comparing F1 and F3 foraminotomies (mean difference $=22.1$ and $\mathrm{Cl}=20.1$ to 24.1). The magnitude of differences between the foraminotomies F2 and F1 and F2 and F3 were similar. The averages were 11.7 and 10.4, respectively, with overlapping confidence intervals. (Table 4)

Table 1. Comparison of right and left sides for each of the three measures the percentage of facet removed.

\begin{tabular}{c|c|c|c|c|c}
\hline & Side & $\mathbf{N}$ & Mean & SD & $\mathbf{p}^{*}$ \\
\hline F1 & $\mathrm{R}$ & 27 & 13,8 & 9,9 & 0,534 \\
\hline & $\mathrm{L}$ & 26 & 15,5 & 9,4 & \\
\hline $\mathrm{F} 2$ & $\mathrm{R}$ & 27 & 24,7 & 9,9 & 0,293 \\
\hline & $\mathrm{L}$ & 26 & 27,7 & 10,7 & \\
\hline $\mathrm{F} 3$ & $\mathrm{R}$ & 27 & 35,3 & 8,3 & 0,324 \\
\hline & $\mathrm{L}$ & 26 & 38,0 & 10,7 & \\
\hline
\end{tabular}

* Student $t$ test to compare two averages.

Table 2. Descriptive statistics of the percentage of facet removed in three foraminotomy between different levels considering both sides.

\begin{tabular}{|c|c|c|c|c|}
\hline \multirow{2}{*}{ Segments } & \multirow{2}{*}{ Statistic } & \multicolumn{3}{|c|}{ Percentage facet resected } \\
\hline & & F1 & F2 & F3 \\
\hline \multirow{5}{*}{ C2-C3 $(n=12)$} & Mean & 17,8 & 27,7 & 39,6 \\
\hline & Median & 15,4 & 29,5 & 39,2 \\
\hline & SD & 9,5 & 9,0 & 7,7 \\
\hline & Min & 6,5 & 10,5 & 27,4 \\
\hline & Max & 35,0 & 41,1 & 56,0 \\
\hline \multirow{5}{*}{ C3-C4 (n=11) } & Mean & 15,6 & 24,8 & 34,0 \\
\hline & Median & 15,8 & 26,4 & 33,9 \\
\hline & SD & 9,8 & 10,5 & 8,6 \\
\hline & Min & 1,7 & 6,6 & 21,2 \\
\hline & Max & 32,0 & 42,0 & 45,9 \\
\hline \multirow{5}{*}{ C4-C5 $(n=11)$} & Mean & 11,6 & 24,4 & 33,4 \\
\hline & Median & 10,3 & 22,7 & 27,8 \\
\hline & SD & 8,9 & 10,4 & 11,3 \\
\hline & Min & 2,1 & 12,7 & 24,8 \\
\hline & Max & 34,9 & 50,4 & 62,6 \\
\hline \multirow{5}{*}{ C5-C6 $(n=11)$} & Mean & 11,3 & 23,8 & 35,9 \\
\hline & Median & 10,4 & 24,4 & 37,1 \\
\hline & SD & 8,4 & 13,2 & 11,5 \\
\hline & Min & 1,9 & 6,7 & 16,3 \\
\hline & Max & 26,6 & 44,4 & 56,4 \\
\hline \multirow{5}{*}{ C6-C7 ( $n=8)$} & Mean & 17,3 & 31,2 & 41,2 \\
\hline & Median & 16,5 & 30,7 & 42,7 \\
\hline & SD & 11,5 & 7,0 & 6,1 \\
\hline & Min & 2,1 & 20,7 & 31,3 \\
\hline & Max & 34,2 & 40,7 & 49,5 \\
\hline
\end{tabular}

Table 3. Estimates of means and confidence intervals for the percentage of facet removed, measured by comparing the levels.

\begin{tabular}{c|c|c|c|c}
\hline \multirow{2}{*}{ Segments* } & Foraminotomy** & \multirow{2}{*}{ Mean } & \multicolumn{2}{|c}{ Confidence Intervals 95\% } \\
\cline { 4 - 5 } & & & Lower Limit & Upper Limit \\
\hline \multirow{3}{*}{ C2-C3 (n=12) } & $F 1$ & 17,8 & 12,2 & 23,3 \\
\cline { 2 - 5 } & $F 2$ & 27,7 & 21,7 & 33,8 \\
\hline & $F 3$ & 39,6 & 34,1 & 45,1 \\
\hline \multirow{3}{*}{ C3-C4 (n=11) } & $F 1$ & 15,6 & 9,8 & 21,3 \\
\cline { 2 - 5 } & $F 2$ & 24,8 & 18,5 & 31,1 \\
\cline { 2 - 5 } & $F 3$ & 34,0 & 28,3 & 39,7 \\
\hline \multirow{3}{*}{ C4-C5 (n=11) } & $F 1$ & 11,6 & 5,9 & 17,4 \\
\cline { 2 - 5 } & $F 2$ & 24,4 & 18,1 & 30,7 \\
\hline \multirow{3}{*}{ C5-C6 (n=11) } & $F 3$ & 33,4 & 27,6 & 39,1 \\
\cline { 2 - 5 } & $F 1$ & 11,3 & 5,5 & 17,1 \\
\cline { 2 - 5 } & $F 2$ & 23,8 & 17,5 & 30,1 \\
\hline \multirow{3}{*}{ C6-C7 (n=8) } & $F 3$ & 35,9 & 30,2 & 41,7 \\
\cline { 2 - 5 } & $F 1$ & 17,3 & 10,5 & 24,1 \\
\cline { 2 - 5 } & $F 2$ & 31,2 & 23,8 & 38,5 \\
\hline
\end{tabular}

* $\mathrm{p}$-Value F-test comparison between the levels $=0.381 .{ }^{* *} \mathrm{p}$-value F-test comparison between measurements $<0.001$

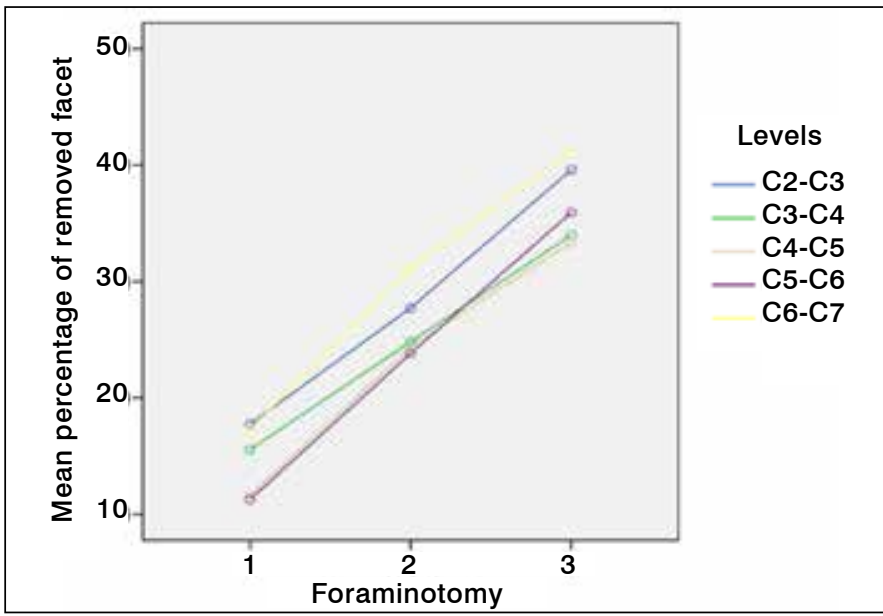

Figure 3. Graphic representation of F1,F2,F3 foraminotomy versus average percentage resected lateral mass in each vertebral segment.

Table 4. Multiple comparison tests among the foraminotomy performed.

\begin{tabular}{c|c|c|c|c}
\hline & \multirow{2}{*}{ Mean difference } & \multirow{2}{*}{$\mathbf{p}$} & \multicolumn{2}{|c}{ Cl 95\% } \\
\cline { 4 - 5 } & & & Lower Limit & Upper Limit \\
\hline F2 - F1 & 11,7 & $<0,001$ & 9,8 & 13,5 \\
\hline F3 - F1 & 22,1 & $<0,001$ & 20,1 & 24,1 \\
\hline F3 - F2 & 10,4 & $<0,001$ & 8,9 & 11,9 \\
\hline
\end{tabular}

\section{DISCUSSION}

Laminoforaminotomies have been used successfully ${ }^{12-14}$ but have possible complications related to cervical instability. Up to $50 \%$ of the facet joint can dry without causing instability. ${ }^{20}$ No studies have assessed the exact size of the foraminotomy needed to expose and release the root compression. Some authors have reported that, in some situations, it is not necessary to resect $50 \%$ of the facet to generate adequate foraminal decompression. ${ }^{14} \mathrm{Kim}$ and $\mathrm{Kim}^{21}$ reported the size of the foraminotomy needed based on the extent of the foraminotomy hole and not based on the percentage of dry facet. The measurements in that study were obtained from CT studies performed post-operatively.

In this study, we chose to perform three sizes of foraminotomy and to assess the percentage of resected facet needed to generate 
adequate foraminal decompression and to accomplish a discectomy. When evaluating the three foraminotomies, it was observed that there was a gradual increase in the percentage of resected facet with statistical differences among all three cases. The F1 facet had less resection than the F2 and F3. F2 was considered ideal for performing the discectomy and foraminal decompression. This foraminotomy was achieved by combining the entire free foramen with perfect identification of the root. If possible, the foramen was subsequently mobilized with microdissectors. More of the facet needed to be removed from the $\mathrm{C} 6-\mathrm{C} 7$ region (mean $=31.2 \%$ ) than from the $\mathrm{C} 5-\mathrm{C} 6$ region (mean $=23.8 \%$ ).

During surgery, it was noted that small amounts of the blade needed to be removed in all situations. Furthermore, at higher levels (C2-C3 and C3-C4), the initial segment of the root seen in $\mathrm{F} 1$ was less extensive than in the other segments, as the C5-C6 and C6-C7 segments seemed to be longer, making it easier to manipulate the root.

When segments were compared with each other, it was noted that the average percentage resected was higher in the C6-C7 facet compared with the other segments. However, this finding was not statistically different. It is noteworthy that the possibility of instability as a postoperative complication may be higher in the C6-C7 foraminotomy.

Based on these results, none of the segments requires resection of more than $50 \%$ of the facet, even in the most extensive foraminotomies (F3). Thus, we can say that, for these procedures, the chance of causing instability is minimal. Furthermore, we find that the ideal foraminotomy (F2) leads to a reduction of the resected facet by $38.5 \%$. It can be inferred that the foraminotomy does not cause postoperative cervical instability.

\section{CONCLUSIONS}

In all segments studied, the removal of approximately $24 \%$ to $32 \%$ of the facet joint allowed for adequate exposure of the dural sac, the root armpit and the foramen. Surgery at the C6-C7 segment required greater resection of the facet to achieve the same effect, but this procedure was still within the safety standards and did not cause instability.

All authors declare no potential conflict of interest concerning this article.

\section{REFERENCES}

1. Heary RF, Ryken TC, Matz PG, Anderson PA, Groff MW, Holly LT, et al. Cervical laminoforaminotomy for the treatment of cervical degenerative radiculopathy. J Neurosurg Spine. 2009;11(2):198-202.

2. Riew KD, Cheng I, Pimenta L, Taylor B. Posterior cervical spine surgery for radiculopathy. Neurosurgery. 2007;60(Supp1 1):S57-63.

3. Lehman RA Jr, Riew KD. Thorough decompression of the posterior cervical foramen. Instr Course Lect. 2007;56:301-9.

4. Scoville WB. Types of cervical disk lesions and their surgical approaches. JAMA. 1966;196(6):479-81.

5. Fessler RG, Sekhar L. Atlas of Neurosurgical Techniques: Spine and Peripheral Nerves. New York: Thieme; 2006.

6. Rengachary SS, Wilkins RH. Neurosurgical Operative Atlas. Chicago: American Association of Neurological Surgeons; 1993.

7. Mayer HM. Minimally Invasive Spine Surgery - A Surgical Manual. New York: Springer; 2006

8. Russell SM, Benjamin V. Posterior surgical approach to the cervical neural foramen for intervertebral disc disease. Neurosurgery. 2004;54(3):662-5.

9. Kumar GR, Maurice-Williams RS, Bradford R. Cervical foraminotomy: an effective treatment for cervical spondylotic radiculopathy. Br J Neurosurg. 1998;12(6):563-8.

10. Grieve JP, Kitchen ND, Moore AJ, Marsh HT. Results of posterior cervical foraminotomy for treatment of cervical spondylitic radiculopathy. Br J Neurosurg. 2000;14(1):40-3.

11. Ducker TB, Zeidman SM. The posterior operative approach for cervical radiculopathy, Neurosurg Clin N Am. 1993;4(1):61-74.

12. Cağlar YS, Bozkurt M, Kahilogullari G, Tuna H, Bakir A, Torun F, et al. Keyhole approach for posterior cervical discectomy: experience on 84 patients. Minim Invasive Neurosurg. 2007;50(1):7-11.

13. Rodrigues MA, Hanel RA, Prevedello DM, Antoniuk A, Araújo JC. Posterior approach for soft cervical disc herniation: a neglected technique? Surg Neurol. 2001;55(1):17-22.

14. Witzmann A, Hejazi N, Krasznai L. Posterior cervical foraminotomy. A follow-up study of 67 surgically treated patients with compressive radiculopathy. Neurosurg Rev. 2000;23(4):213-7.

15. Abbed KM, Coumans JV. Cervical radiculopathy: pathophysiology, presentation, and clinical evaluation. Neurosurgery. 2007;60(Supp1 1):S28-34

16. Aldrich F. Posterolateral microdisectomy for cervical monoradiculopathy caused by posterolateral soft cervical disc sequestration. J Neurosurg. 1990:72(3):370-7.

17. Blondi C, Moroni A, Cantagalli S, Trinchese L, Vicenzi G, Pezzuto V, et al. The surgical treatment of cervical disc herniation. Chir Organi Mov. 1990;75(4):311-4.

18. Korinth MC. Treatment of cervical degenerative disc disease - current status and trends. Zentralbl Neurochir. 2008;69(3):113-24.

19. Boehm H, Greiner-Perth R, El-Saghir H, Allam Y. A new minimally invasive posterior approach for the treatment of cervical radiculopathy and myelopathy: surgical technique and preliminary results. Eur Spine J. 2003;12(3):268-73.

20. Zdeblick TA, Zou D, Warden KE, McCabe R, Kunz D, Vanderby R. Cervical stability after foraminotomy. A biomechanical in vitro analysis. J Bone Joint Surg Am. 1992;74(1):22-7.

21. Kim KT, Kim YB. Comparison between open procedure and tubular retractor assisted procedure for cervical radiculopathy: results of a randomized controlled study. J Korean Med Sci. 2009;24(4):649-53. 